\title{
Seabird foraging behaviour indicates prey type
}

\author{
Kyle Hamish Elliott ${ }^{1, *}$, Kerry Woo ${ }^{2,3}$, Anthony J. Gaston ${ }^{2,3}$, Silvano Benvenuti ${ }^{4}$, \\ Luigi Dall'Antonia ${ }^{5}$, Gail K. Davoren ${ }^{1}$ \\ ${ }^{1}$ Department of Zoology, Z320 Duff Roblin Building, University of Manitoba, Winnipeg, Manitoba R3T 2N2, Canada \\ ${ }^{2}$ Department of Biology, University of Ottawa, 30 Marie Curie, University of Ottawa, Ottawa, Ontario K1N 6N5, Canada \\ ${ }^{3}$ Environment Canada, National Wildlife Research Centre, Carleton University 1125 Colonel By Drive, Ottawa, \\ Ontario K1S 5B6, Canada \\ ${ }^{4}$ Dipartimento di Biologia, Ecologia ed Evoluzione, University of Pisa, Via volta 6, 56126 Pisa, Italy \\ ${ }^{5}$ Istituto di Elaborazione dell'Informazione, C. N. R., Via S. Maria 46, 56126 Pisa, Italy
}

\begin{abstract}
To investigate how a generalist marine predator modifies its foraging behaviour by prey type, we attached time-depth-temperature recorders to chick-rearing thick-billed murres $(n=204)$ at Coats Island, Nunavut, Canada from 1999 to 2007. Predators varied their behavior along 3 major 'axes': foraging effort, prey depth and prey lifestyle (benthic/pelagic). Dive behaviours for different prey - fish doctor, squid, sandlance, amphipods, snakeblenny, daubed shanny, sandlance and Arctic shanny - were discriminated from one another in a discriminant analysis of dive variables and these prey were therefore considered 'specialist' prey items. Specifically, amphipods were captured during V-shaped dives near the colony with a slow bird descent rate, squid were captured during deep V-shaped dives in cold water and fish doctor were captured during a long series of U-shaped dives in relatively warm water far from the colony. Arctic shanny and snakeblenny tended to be taken at moderate distances from the colony, with snakeblenny taken at deeper depths. Daubed shanny captures showed a bimodal distribution, with some taken at shallow depths far from the colony and others at deep depths close to the colony. Dive behaviours for Arctic cod, capelin and sculpin overlapped both with each other and the behaviours for specialist prey items and, therefore, were classified as 'generalist' prey items. In general, V-shaped dives preceded deliveries of pelagic prey items and U-shaped dives preceded deliveries of benthic prey items. Our results strongly suggest that generalist marine predators use stereotypic behaviour to forage for prey items, based on previous knowledge about what locations/strategies maximized intake for a given prey type.
\end{abstract}

KEY WORDS: Thick-billed murre $\cdot$ Uria lomvia $\cdot$ Seabirds as indicators $\cdot$ Dive shape $\cdot$ Foraging strategies $\cdot$ Specialization

Resale or republication not permitted without written consent of the publisher

\section{INTRODUCTION}

Early theoretical formulations of foraging ecology characterized animals as naïve foragers, randomly encountering prey items while foraging (MacArthur \& Pianka 1966, Ward \& Zahavi 1973, Orians \& Pearson 1979). Recent empirical results, however, have shown that predators specializing on specific prey types ('specialists'), such as a single fish species, actively search out encounters with specific prey by returning to loca- tions known to have an abundance of that particular prey item (Davoren et al. 2003, Weimerskirch et al. 2005, Wilson et al. 2005). Nonetheless, it is unclear whether predators that prey on a variety of prey types ('generalists') also (1) actively change their behaviour to search for and capture specific prey items or (2) move randomly through a habitat and consume prey items as they are encountered (Barrett 2002, Tremblay et al. 2005). For example, it is unclear whether the proportions of prey items in the diets of generalist preda- 
tors reflect relative abundance in the environment, predator selection of more energetically profitable items over less profitable items or reflect relative abundance of individual 'specialists' of a species within the population (Gaston 2004).

Generalist seabirds are potentially ideal indicators for changes in the marine ecosystem because they are top predators that are easily monitored and that provide simultaneous information on several prey items, and, potentially, several trophic levels (Montevecchi \& Myers 1996, Furness \& Camphuysen 1997). In arctic environments (where use of seabirds to monitor environmental change is especially important because conventional marine sampling is prohibitively expensive) many seabirds are generalists. Because the foraging behaviour of generalist predators is poorly understood, it is unclear whether dietary shifts reflect changes in prey abundance or changes in predator behaviour (Bryant et al. 1999, Gaston et al. 2003). Thus, whereas specialist seabirds are frequently used as indicators for spatial and temporal changes in fish populations (Aebischer et al. 1990, Monaghan 1996, Davoren \& Montevecchi 2003, Miller \& Sydeman 2004) and for age-specific recruitment in fish (Barrett et al. 1990, Bertram \& Kaiser 1993), generalist seabirds are used less often (Montevecchi \& Myers 1996, Bryant et al. 1999, Gaston et al. 2003).

Seabird foraging behavior is often a better indicator of fish abundance than colony measures, such as adult body condition or breeding success, because adults can buffer changes in prey availability through changes in provisioning behavior (Monaghan et al. 1994, Monaghan 1996, Grémillet 1997, Jodice et al. 2006, Harding et al. 2007). With the invention of miniaturized bird-borne devices, seabird biologists have been able to examine many aspects of foraging behavior that were formerly difficult or impossible to observe (e.g. Charrassin et al. 2001, Catry et al. 2004, Takahashi et al. 2004, Weimerskirch et al. 2005).

Dive shape has been proposed as a potential tool for inferring prey distribution and foraging locations through predator behaviour, although the interpretation of dive shape is complex. V-shaped or bounce dives are sometimes thought to represent predator avoidance (Schreer et al. 2001), travel in pinnipeds (Schreer et al. 2001) and penguins (Chappell et al. 1993, Wilson et al. 1996, Kirkwood \& Robertson 1998), or exploration in pinnipeds (Schreer et al. 2001) and penguins (Kirkwood \& Robertson 1998, RopertCoudert et al. 2002, Lescroël \& Bost 2005). Nonetheless, V-shaped dives sometimes form a large percentage of dives, show strong diel variation in maximum depth, and/or regularly exceed aerobic dive limits, showing that they also have a foraging function in pinnipeds (Boyd \& Croxall 1992, Burns et al. 1997), penguins (Tremblay \& Cherel 2000, Schreer et al. 2001) and alcids (Kato et al. 2003, Kuroki et al. 2003). Specifically, V-shaped dives are often thought to represent pelagic foraging (e.g. Tremblay \& Cherel 2000). U-shaped dives, sometimes called square or flatbottomed dives, are usually thought to represent prospecting (Ropert-Coudert et al. 2002) or foraging in pinnipeds (Gazo et al. 2006), penguins (Kirkwood \& Robertson 1997, Radl \& Culik 1999, Pütz \& Cherel 2000, Tremblay \& Cherel 2000), alcids (Croll et al. 1992, Mori et al. 2002) and cormorants (Schreer et al. 2001, Tremblay et al. 2005). Benthic foraging is often characterized by dive bouts in which subsequent square dives are flat and to the same depth (RopertCoudert et al. 2002, Takahashi et al. 2003, Lescroël \& Bost 2005), whereas pelagic foraging is often characterized by V-shaped dives (Tremblay \& Cherel 2000).

Because most seabirds and pinnipeds make relatively long foraging trips and return with many prey items, it is difficult to link dive shape, or other dive characteristics to specific prey items. Thick-billed murres (Uria lomvia, hereafter 'murres') provide an opportunity for overcoming some of these difficulties because they usually return to the colony with a single prey item ('single prey loaders') and yet are sufficiently large that recording equipment can be deployed with limited impact on dive behavior. Murres in the Low Arctic are particularly well-suited for these comparisons because individuals there have an especially diverse diet (Gaston et al. 2003).

To determine whether murre foraging strategies (with particular emphasis on dive behaviour) differ when searching for and capturing different prey types, we combined identification of prey deliveries at the colony with information on foraging behavior from time-depth-temperature recorders (TDRs) attached to adult birds during the chick-rearing season. We made the assumption that the last dive represented the dive during which prey was captured for the chick and that the last dive bout represented foraging behavior typical of searches for the prey species caught.

\section{MATERIALS AND METHODS}

Our observations were made at the Coats Island West Colony (Fig. 1), Nunavut, Canada (Gaston et al. 2003, 2005) during the breeding season. Murres were caught with a noose pole (1999: $\mathrm{n}=24 ; 2000: \mathrm{n}=7$; 2004: $\mathrm{n}=23 ;$ 2005: $\mathrm{n}=33 ;$ 2006: $\mathrm{n}=80 ; 2007: \mathrm{n}=37$ ). Handling time was always $<10 \mathrm{~min}$ and usually $<5$ min. All procedures were approved under the guidelines of the Canadian Committee for Animal Care (Protocol Number F04-030).

TDR Observations. During 1999-2000, we used TDRs identical to those described by Falk et al. (2000, 


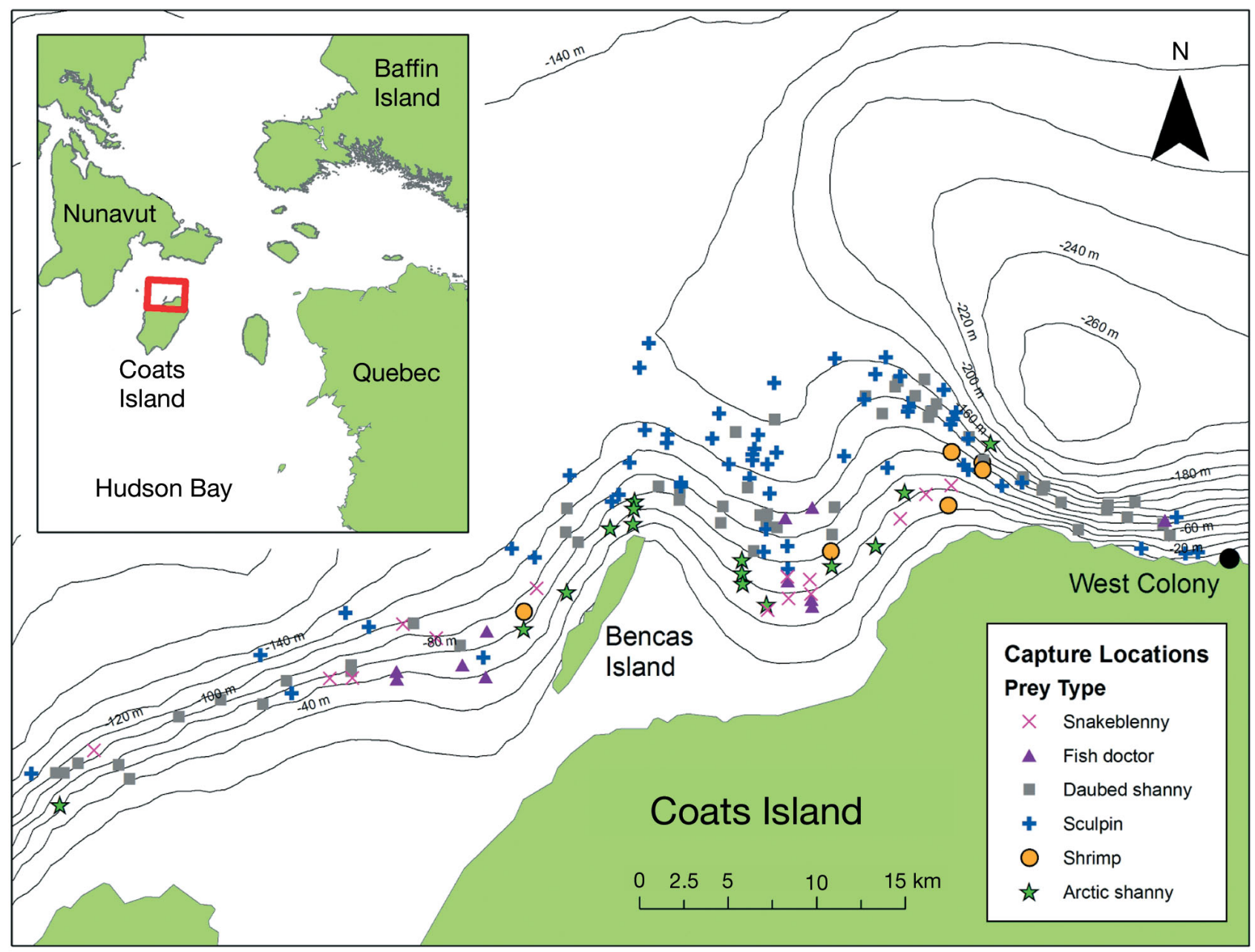

Fig. 1. Locations where benthic prey items were taken by thick-billed murres in the vicinity of the West Colony, Coats Island, Nunavut (Canada), as determined by flight time from the colony and maximum depth of the final dive prior to prey delivery. Depth contours are in $20 \mathrm{~m}$ intervals. Coordinates of West Colony are $62^{\circ} 57^{\prime} \mathrm{N}, 82^{\circ} 00^{\prime} \mathrm{W}$

2002) and Benvenuti et al. (1998). The 'Benvenuti' TDRs (length: $80 \mathrm{~mm}$; width: $23 \mathrm{~mm}$ (tip) to $30 \mathrm{~mm}$ (base); depth: 13 to $18.5 \mathrm{~mm}$ ) housed a pressure sensor and 2 motion recorders. The motion recorders sampled every $8 \mathrm{~s}$ and distinguished flying, swimming and resting. The pressure sensors sampled every $4 \mathrm{~s}$ and recorded to a maximum depth of $76 \mathrm{~m}$. These TDRs were fitted to feathers (using tape) along the midline of the lower back so as to minimize drag.

During 2004 to 2006 we secured LOTEK 1100LTD TDRs (Lotek Marine Technology) with duct tape to plastic bands that were attached to the legs of murres (murres do not use their legs for underwater propulsion). The 'Lotek' TDRs were cylindrical (mass: $4.5 \mathrm{~g}$; diameter: $1 \mathrm{~cm}$; length: $3.3 \mathrm{~cm}$ ) and attached parallel to the leg with the rounded end facing toward the body and the pressure sensor facing toward the foot. Lotek TDRs sampled temperature and pressure every $3 \mathrm{~s}$ and were calibrated by the company prior to the field sea- son with absolute accuracy of $\pm 0.1 \mathrm{~m}$. A SCUBA diving session to $30 \mathrm{~m}$ prior to the field season revealed a precision of $\pm 0.1 \mathrm{~m}$. Drift of $\pm 1 \mathrm{~m}$ was evident in some cases and error was also present through changes in velocity and acceleration (Bernoulli effect). Therefore, total absolute error was likely to be about $\pm 2 \mathrm{~m}$ and dives shallower than $3 \mathrm{~m}$ were ignored. We used the temperature log from the TDR to determine whether the bird was on the water, in the air or at the colony (Tremblay et al. 2003; Fig. 2). Water temperature was always $-2^{\circ} \mathrm{C}$ to $6^{\circ} \mathrm{C}$ and air temperature was always $8^{\circ} \mathrm{C}$ to $20^{\circ} \mathrm{C}$. Because we also knew when the bird arrived at the colony from our continuous watches (see below), we were able to determine flight time between the last dive bout and delivery.

Back-mounted TDRs are known to impact murre provisioning rates, trip duration and mass loss (Falk et al. 2000, 2002, Watanuki et al. 2001, Tremblay et al. 2003, Paredes et al. 2004, Elliott et al. 2007). To deter- 


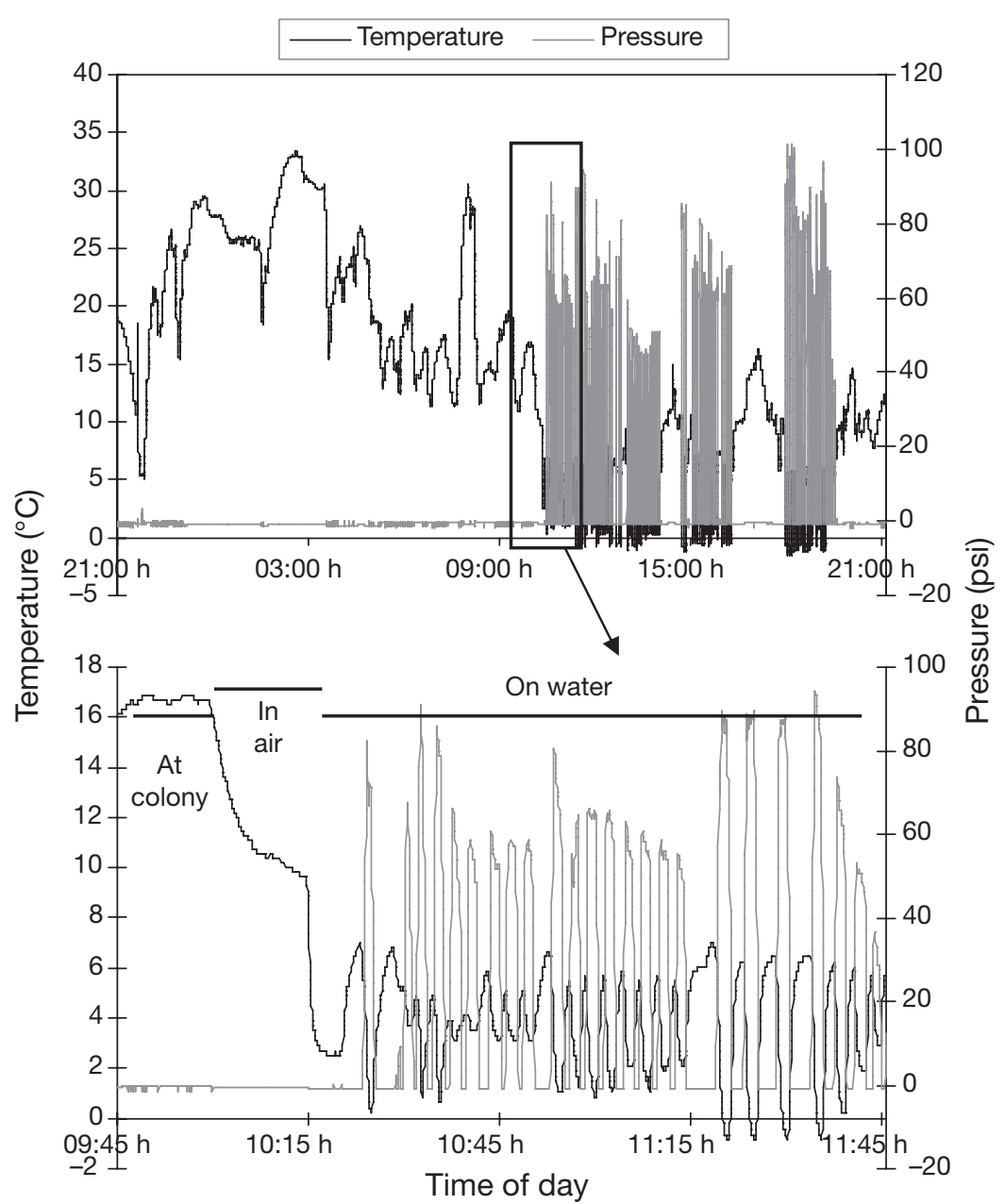

Fig. 2. Reading from a time-depth-temperature recorder attached to the leg of a thick-billed murre at 21:00 h on August 13, 2004. The lower plot is a subsection of the upper plot. Temperature reading shows when the bird is at the colony (temperature near body surface temperature $\sim 18^{\circ} \mathrm{C}$ ), in the air (temperature near air temperature $\sim 9^{\circ} \mathrm{C}$ ) and on the water (temperature at water temperature $\sim 6^{\circ} \mathrm{C}$ ). Pressure is in psi (pounds per square inch; $1.0 \mathrm{psi}=0.069$ bar at sea level)
(21:00 to 04:00 h, Croll et al. 1992), we ignored time of day as a factor influencing dive parameters in our analyses. Sandlance were delivered to chicks after $25 \%$ of the dives and capelin after $35 \%$ of the dives within the 21:00 to 04:00 $\mathrm{h}$ time period. Thus, the effect of time of day on observed dive parameters would be reduced for other prey species.

We converted flight time into distance assuming $75 \mathrm{~km} \mathrm{~h}^{-1}$ flight speed, ignoring variation in flight velocity with wind speed, load and other factors (Elliott \& Gaston 2005). This calculation assumed that murres returned in a straight line from their foraging destination, as predicted from theoretical considerations for single-prey loaders and shown for murres from colonies in Iceland (Benvenuti et al. 1998) and Greenland (Falk et al. 2000, 2002). We assumed that the maximum depth of the last dive prior to returning to the colony represented the depth at which the prey item was collected because for all prey types final dives were on average shorter in duration, but not consistently shallower than the average for the entire final dive bout, suggesting that the final dive was aborted once a prey item was captured.

Feeding watches. In conjunction with deployment of the TDRs, continuous observational watches of breeding sites were also carried out. All observations were made from blinds situated on the study plots ( $Q, T$ and $Z$ plots) within $5 \mathrm{~m}$ of the birds. Hipfner et al. mine whether our leg-mounted devices significantly impacted feeding rates, we compared chick feeding rates of individuals with TDRs to their partners without TDRs during the same feeding watch, and feeding rates of the same individuals with or without TDRs (in sequential feeding events with and without TDRs). Because the back-mounted TDRs likely decreased dive depth, duration and descent rate relative to birds with leg-mounted TDRs (Elliott et al. 2007), we either conducted separate analyses with and without the backmounted TDRs (see Fig. 5) or we excluded the backmounted TDR data from analyses (see Figs. 4, 6, Table 2). Because only $9 \%$ of the dives $(1999: 7 / 81 ; 2000$ : 0/10; 2004: 3/50; 2005: 9/129; 2006: 35/310; 2007 : $7 / 146)$ were within the period of day when murre dive depth is reduced due to decreased light availability
(2006) show that there is no difference in feeding habits between plots. Continuous feeding watches (24 or $48 \mathrm{~h}$ ) were conducted at Q-Plot during 1999 (28-30 July, 7-9 August, 12-14 August), 2000 (30 July, 9-10 August), 2004 (30 July, 8 August, 14 August), 2005 (24-26 July, 2-3 August, 7-8 August), 2006 (24-26 July, 1-2 August, 6-8 August, 15 August) and 2007 (29-30 July, 3-5 August, 11 August), as well as 2 shorter feeding watches (TPlot: 14:00-19:00 h, 28 July 2005; Z-Plot: 12:00-17:00 h, 10 August 2005). We did not conduct feeding watches when it was too dark to see deliveries (roughly 01:00-02:00 h in late July and 23:00-04:00 h in mid August) because nestlings are rarely fed at this time (Gaston et al. 2003). During these observation sessions, prey items delivered to the colony for chick provisionings were identified whenever possible. 
Table 1. Prey taxa (including habitat and growth information) collected from thick-billed murre ledges at Coats Island (1984 to 2004; see Fig. 1 for location). Age (in years) refers to the modal age, based on fork lengths observed. Depth refers to preferred depth ( $\mathrm{S}:<60 \mathrm{~m}_{i} \mathrm{D}:>90 \mathrm{~m}$; V: variable). Substratum refers to preferred substratum ( $\mathrm{S}=\mathrm{Sandy}, \mathrm{P}=$ epipelagic, $\mathrm{K}=$ Kelp, $\mathrm{R}=$ Rocky). Spawning period refers to average spawning period at closest reported location (S: June to August; F: September to October; W: November to May)

\begin{tabular}{|c|c|c|c|c|c|}
\hline Common name & Latin name & Age & Depth & $\begin{array}{c}\text { Sub- } \\
\text { stratum }\end{array}$ & $\begin{array}{l}\text { Spawning } \\
\text { period }\end{array}$ \\
\hline Sandlance & Ammodytes hexapterus & 1 & $\mathrm{~S}$ & S & $\mathrm{W}$ \\
\hline Arctic cod & Boreogadus saida & 1 & $\mathrm{~V}$ & $\mathrm{P}$ & W \\
\hline \multirow{7}{*}{ Sculpin } & Cottidae & & & & \\
\hline & Mуохосерhalus scorpius & & $\mathrm{S}$ & S K & $\mathrm{W}$ \\
\hline & Myoxocephalus aenaeus & & S & S & $\mathrm{W}$ \\
\hline & Icelus spatula & & $\mathrm{V}$ & $\mathrm{S}$ & $\mathrm{F}$ \\
\hline & Triglops pingeli & & $\mathrm{D}$ & $\mathrm{P}$ & $\mathrm{W}$ \\
\hline & Triglops murrayi & & $\mathrm{D}$ & S P & $\mathrm{S} ?$ \\
\hline & Gymnocanthus tricuspis & & $\mathrm{S}$ & S R & W \\
\hline Atlantic Poacher & Leptagonus decagonus & & $\mathrm{D}$ & $\mathrm{S}$ & W \\
\hline Snakeblenny & Eumesogrammus praecisu & & $\mathrm{S}$ & $\mathrm{R}$ & $\mathrm{F}$ \\
\hline Fish doctor & $\begin{array}{l}\text { Gymnelus spp. } \\
\text { Gymnelus viridis } \\
\text { Gymnelus retrodorsalis }\end{array}$ & & S & S R K & $\mathrm{F}$ \\
\hline Daubed shanny & Leptoclinus maculates & & $\mathrm{D}$ & S R & $\mathrm{W}$ \\
\hline Capelin & Mallotus villosus & 1 & $\mathrm{~V}$ & $\mathrm{P}$ & $\mathrm{S}$ \\
\hline Arctic shanny & Stichaeus punctatus & $2+$ & $\mathrm{S}$ & $\mathrm{R}$ & $\mathrm{W}$ \\
\hline Squid & Gonatus fabricii & 1 & $\mathrm{D}$ & $\mathrm{P}$ & $\mathrm{F}$ ? \\
\hline Shrimp & $\begin{array}{l}\text { Decapoda spp. } \\
\text { Argis dentata } \\
\text { Lebbeus groenlandicus } \\
\text { Pandalus montagui } \\
\text { Sclerocrangon boreas }\end{array}$ & & $\mathrm{V}$ & $\mathrm{R}$ & $\mathrm{S}$ \\
\hline Amphipod & Parathemisto libellula & & $\mathrm{V}$ & $\mathrm{P}$ & $\mathrm{F}$ ? \\
\hline
\end{tabular}

provide a context for understanding the patterns presented later. We emphasize that the ecologies of many of these taxa are poorly understood and much variation exists within each taxon.

Dive shape. Dives were visually classified by dive profile into 5 categories (Lescroël \& Bost 2005; Fig. 3). Our categories focused on the bottom phase to avoid complications arising from confounding shape with depth. W-dives were approximately symmetrical with pronounced ragged bottoms. V-dives were symmetrical dives with no bottom phase. U-dives had $>3$ consecutive identical measurements during the bottom phase while $\mathrm{u}$-dives had a definite bottom phase with $\leq 3$ consecutive identical measurements. I-dives (irregular) were all others, such as those that repeatedly increased and decreased in depth. For the purposes of analyses, we used the proportion of $\mathrm{V}$-dives as a proxy variable because $96 \%$ of dives were either U- or V-dives, and, therefore, this variable captured virtually all of the information on dive shape. Croll et al. (1992) and Mori et al. (2002) assumed U-dives were associated with Arctic cod, whereas Jones et al. (2002) stated that U-dives usually preceded

Prey species. A subset of prey items collected on colony ledges between 1984 and 2002 were sent to the Canadian Museum of Nature for positive identification (Table 1). This subset was biased towards prey items that were not readily identifiable. Although both Ammodytes specimens submitted were classified as A. hexapterus, 2 small (1.1 $\mathrm{g}$ and $2.9 \mathrm{~g}$ ) specimens collected from nearby Digges Island were identified as A. dubius. All specimens of Gymnelus spp. (n = 24) were identified as $G$. viridis, with the exception of 2 specimens identified as $G$. retrodorsalis. The sculpins (Cottidae) were difficult to identify in the field. A single specimen of Icelus spatula was collected (1 out of 121 or $1 \%$ of sculpins identified to genus). Myoxocephalus made up 12 (10\%) and Gymnocanthus $10(8 \%)$ of the sculpins that were identified to genus. All Gymnocanthus were identified as G. tricuspis, and 7 Myoxocephalus were identified as M. scorpius, 4 as M. scorpioides and 1 as $M$. aeneus. Triglops made up 93 out of 121 (82\%) identified to genus. T. pingeli made up 23 out of 28 (82\%) of Triglops identified to species, and T. murrayi made up the remainder (18\%). Because of the difficulty of identifying sculpins in the field, we pooled all sculpins together for analyses. General habitat and life history data are also presented in Table 1 to deliveries of daubed shanny. In 1999-2000, because dive depth was only recorded to $76 \mathrm{~m}$, we used the activity recorder to estimate shape for dives exceeding $76 \mathrm{~m}$ (reduced activity occurs during the bottom phase of U-dives). We also calculated the time-allocation-atdepth (TAD) Index (Takahashi et al. 2003) for each dive as an alternative index of dive shape. This index varies between 0.5 and 1.0 , with 0.5 representing Vshaped dives (time is evenly allocated at all depths) and 1.0 representing $\mathrm{U} 1$-shaped dives (time is allocated primarily at the bottom).

Descent rate and water temperature. For each TDR measurement, we calculated descent rate at a given sampled depth using the formula:

$$
U_{n}=-\frac{\frac{d_{n+1}-d_{n}}{3}+\frac{d_{n}-d_{n-1}}{3}}{2}=\frac{d_{n-1}-d_{n+1}}{6}
$$

where $d_{n-1}, d_{n}$ and $d_{n+1}$ are the depths at consecutive sampling times spread $3 \mathrm{~s}$ apart, and $U_{n}$ is the speed at sample time $n$. Because murres hold their bodies nearly vertical during descent, descent rate is very close to actual swim speed (Lovvorn et al. 1999, 2004). We examined descent rates only at depths $>10 \mathrm{~m}$ shal- 


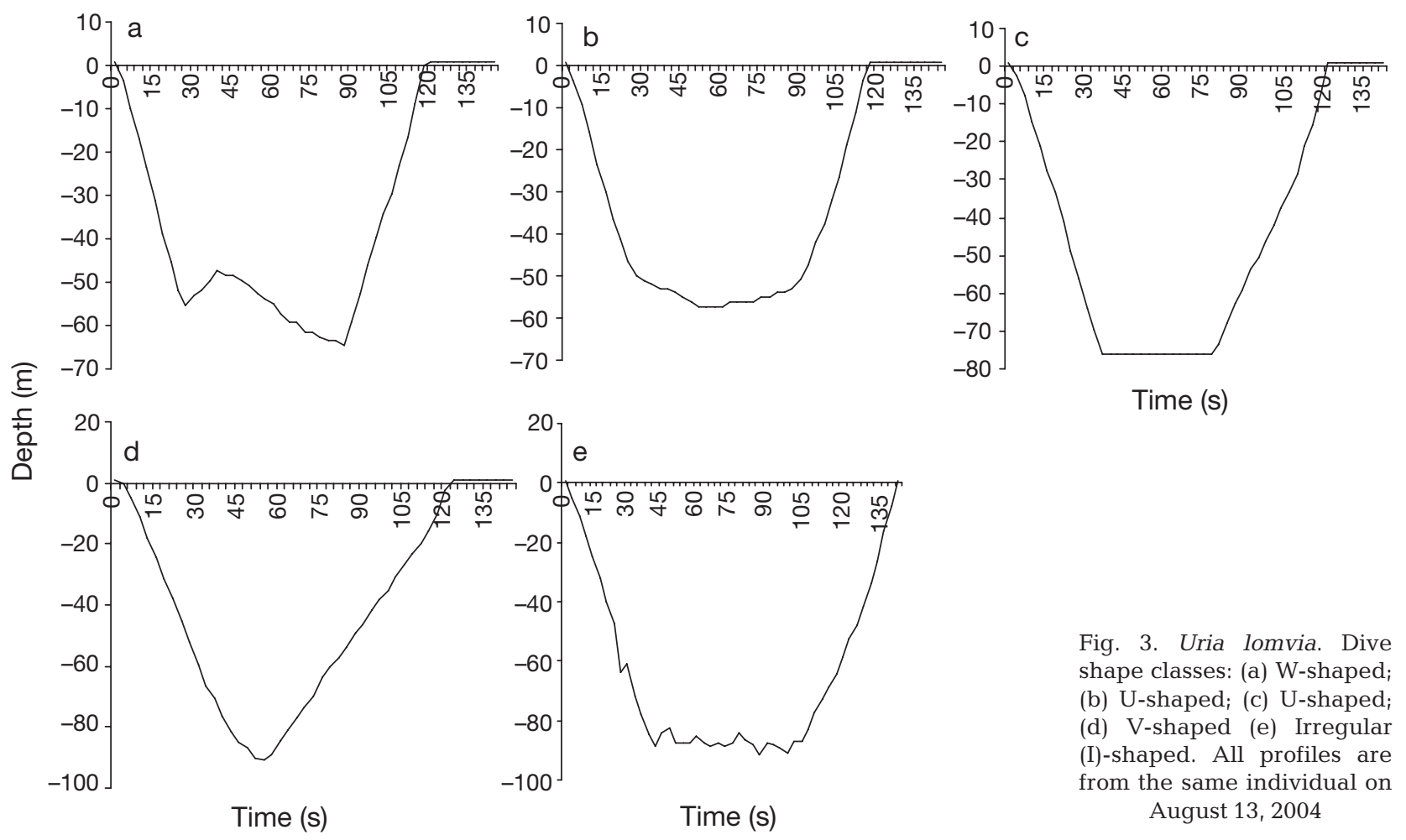

lower than maximum dive depths to avoid including bottom time or deceleration in our calculations for descent rate.

Mehlum et al. (2001) and Watanuki et al. (2001) used temperature recorders in Svalbard to determine murre feeding locations, as depth-temperature profiles differed greatly depending on location within the fjord where their murre colony was located. We analysed surface temperature, depth-temperature profile, and minimum temperature by prey items to determine whether there was any indication that prey items were collected from different locations or from different temperature regimes. We placed all Lotek TDRs in water of known temperature and determined a time constant of $0.036 \pm 0.005$ (SE) s${ }^{-1}$ for the TDR thermistor. Because the averaging method (Mehlum et al. 2001, Watanuki et al. 2001) cannot be used for Vshaped dives near maximum depth, we used Newton's Law of Cooling to estimate ambient temperature $\left(T_{\mathrm{a}}\right)$ at time $t$, based on the average of the temperature difference between consecutive measurements:

$$
T_{\mathrm{a}}=0.5 \times\left(\frac{T_{t-3} \mathrm{e}^{-0.09}-T_{t}}{\mathrm{e}^{-0.09}-1}+\frac{T_{t-6} \mathrm{e}^{-0.18}-T_{t}}{\mathrm{e}^{-0.18}-1}\right)
$$

As descent rate and $T_{\mathrm{a}}$ changed nonlinearly with depth (Watanuki et al. 2001, 2003, 2006, Gaston 2004; Fig. 4), we used Akaike's Information Criterion (AIC) to determine the best polynomial approximation to the average descent rate-depth and $T_{\mathrm{a}}$-depth function across all prey deliveries (descent rate: $\triangle \mathrm{AIC} 5$ th order:
$0.0 ; \Delta$ AIC 6 th order: $5.9 ; \Delta$ AIC 4 th order: $10.2 ; T_{\mathrm{a}}: \Delta$ AIC 5th order: $0.0 ; \Delta$ AIC 6th order: $2.2 ; \Delta$ AIC 4 th order: 42.5). To calculate a descent rate index and water temperature index on the final dive prior to prey delivery, we averaged the difference between measured $U_{n}$ or $T_{\mathrm{a}}$ and that predicted by the 5 th order best fit function.

Dive bout measurements. We used sequential differences analysis to define dive bouts (Mori et al. 2001; difference criterion $=37.4 \mathrm{~m}$ or $63.4 \mathrm{~s}$ ). We compiled the following parameters for the final dive preceding each prey delivery: (1) depth, (2) duration, (3) temperature index, (4) minimum temperature, (5) average sea surface temperature, (6) descent rate index, (7) TAD index and (8) return flight dive. We compiled the following additional parameters for the final dive bout preceding each prey delivery: (9) average and (10) SD of depth, (11) average and (12) SD of duration, (13) average and (14) SD of surface pause duration, (15) average ratio of surface pause to dive duration, (16) number of dives and (17) proportion of V-shaped dives. As many of these parameters are highly correlated, we used a principal component analysis (PCA) to reduce the number of dimensions selected for analysis to 4 non-redundant variables. We selected the variables by considering only the 3 axes (eigenvectors) explaining $>10 \%$ of the variation, and by selecting the variable with the highest loading on each of these 3 axes. Because several of the dive bout variables were only applicable for bouts with $>3$ dives (e.g. SD of surface pause duration), we calculated 2 PCAs: one that 


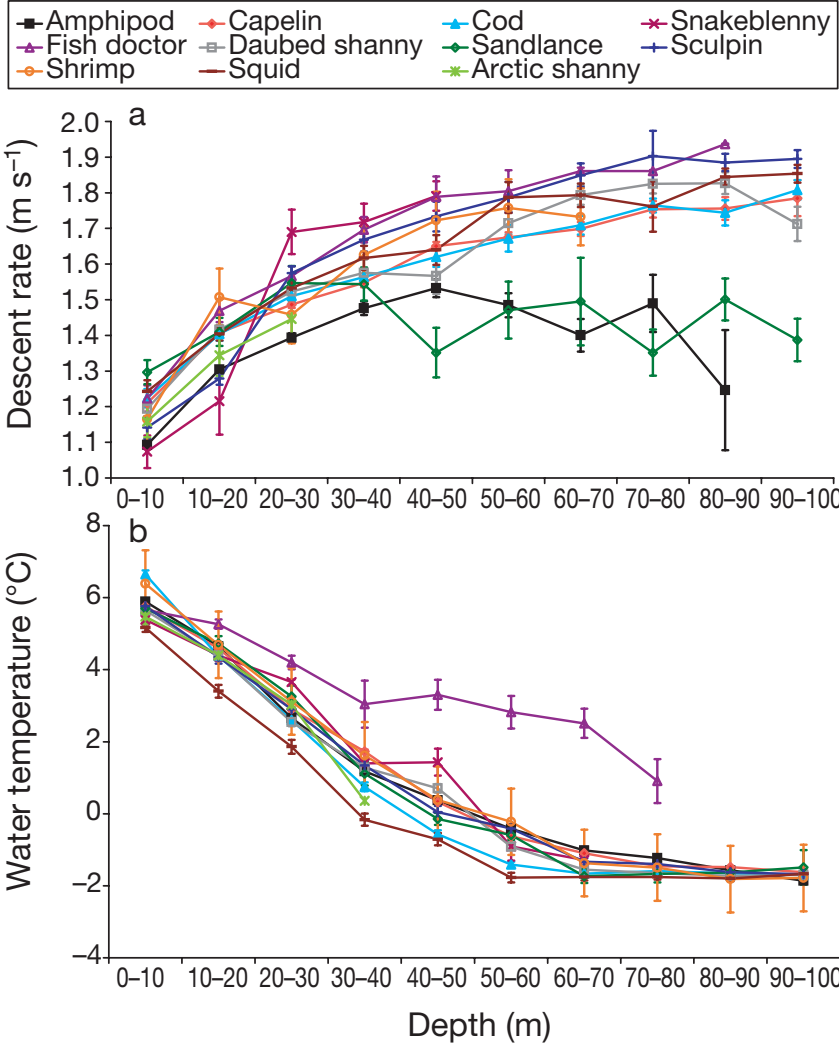

Fig. 4. Uria lomvia. (a) Descent rate increases and (b) water temperature decreases with depth during the final dive preceding the delivery of different prey items at Coats Island, Nunavut, Canada 2004 to 2007 . Values were averaged within each $10 \mathrm{~m}$ bin. Bins with only data from a single dive were excluded. For descent rate, values $<10 \mathrm{~m}$ from maximum depth were excluded. Data are means \pm SE

included all dive bouts but only a reduced set of variables and a second that included all variables but only dive bouts with $>3$ dives. The 2 PCAs selected the same variables for 2 axes. For a third axis, the PCA including all bouts selected the variable 'number of dives', whereas the PCA including only bouts with $>3$ dives selected the variable 'flight time'. Because of the ambiguity of this analysis, we selected both variables for inclusion in the multigroup discriminant analysis (MDA).

Statistical analyses. All statistical analyses were completed in R 3.2.1. Prior to using parametric statistics, we tested for normality (Shapiro-Wilk test) and homogeneity of variance (Bartlett's test). Proportions were arcsine-transformed and variables that were not normally distributed were log-transformed prior to analyses. Unless otherwise indicated, means \pm SE are presented. To determine whether foraging trips that resulted in the same prey type clustered together, we completed a MDA. Because there were fewer than 10 shrimp observations, we grouped shrimps with
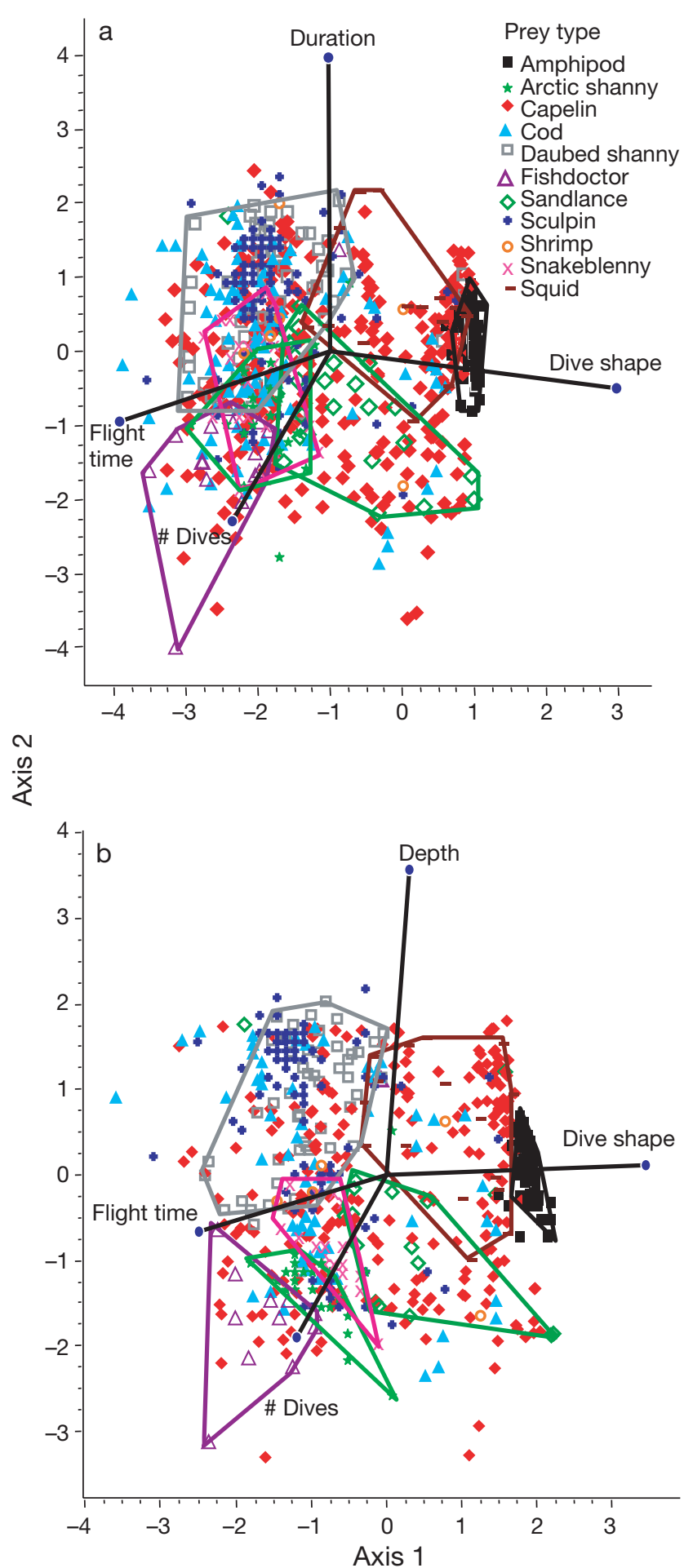

Fig. 5. Multigroup discriminant analyses for thick-billed murre prey items delivered. Polygons represent minimum convex polygons that include $95 \%$ of the points and are only shown for groups that separate significantly. (a) 1999 to 2007 ( $\mathrm{n}=713$ deliveries); (b) 2004 to 2007 ( $\mathrm{n}=614$ deliveries). Axes are return flight time after final dive (Flight time), number of dives in the preceding dive bout (\# Dives), duration of the final dive (Duration), final dive depth (Depth) and proportion of V-shaped dives in the final dive bout (Dive shape) 
amphipods. We used minimum convex polygon algorithms to cluster foraging parameters associated with the same prey type. The MDAs (Fig. 5) included the 4 variables that contributed the highest loading to the first 3 vectors of the PCA, with 2 variables included for PC2 (see above). We calculated 2 different MDAs. The first (Fig. 5a) replaced depth with duration because depth was not measured below $76 \mathrm{~m}$ in 1999 and 2000. The second MDA (Fig. 5b) included depth and was therefore restricted to 2004-2007. To determine whether dive parameters differed by prey type, we used ANOVA with prey type as model effects and dive parameters as dependent variables. To account for individual specialization in dive behaviour and eliminate pseudoreplication, we randomly selected a single dive for each prey item-individual combination and performed the ANOVA on the reduced data set.

Mapping. We obtained depth data for the study area from the General Bathymetric Chart of the Oceans (GEBCO) at 1' resolution. We then used ArcGIS 9.0 Geostatistical Wizard and the IDW method to create a layer measuring cost-weighted distance from the colony, with cost of traveling over land set at $10000 \times$ the cost of traveling over water (murres never travel overland). We selected the unique combination of depth and cost-weighted distance for each delivery of a benthic prey item by assuming that maximum dive depths for these deliveries were equal to the ocean depth, that birds returned via the shortest route possible that did not pass over land and that they flew at $75 \mathrm{~km} \mathrm{~h}^{-1}$ from the west (Elliott \& Gaston 2005).

The assumption that most foraging occurs to the west of the colony was tested by (1) attaching radio transmitters (Holohil Systems) with tape to the bands of 11 birds in 1998 and recording the direction of fixes that were $>2 \mathrm{~km}$ from the colony (e.g. were not associated with preening or socializing), (2) conducting counts (from near the base of the colony) of the number of birds incoming to the colony from north, east and west quadrants during $10 \mathrm{~min}$ intervals from 15:00 to 16:00 h (each quadrant was counted twice) on 24 to 26 July 1998 and 5 min intervals from 20:00 to 21:00 h (each quadrant was counted 4 times) on 8 to 10 August 2007, and (3) conducting 1 to $2 \mathrm{~h}$ simultaneous observations (using 2 observers) from the east and west side of the west colony cove, alternating between $5 \mathrm{~min}$ observations of the number of incoming birds and 5 min observations of the proportion of incoming birds with fish. The latter observations occurred at randomly selected times between 08:00 and 20:00 h on $10 \mathrm{~d}$ between 25 July and 10 August 2006.

Resource selection functions. The bathymetric maps were then used to determine the proportion of prey items taken at different depths and distances from the colony after correcting for the availability of depths and distances around the colony. The resource selection function (RSF) for pelagic prey items was calculated by dividing the number of prey items collected within each $10 \mathrm{~km}$ bin by the amount $\left(\mathrm{km}^{2}\right)$ of ocean surface available within that distance range to the west of the colony. The distance RSF for benthic prey items was calculated from the ocean surface area available with depth $<140 \mathrm{~m}$. The depth RSF was only calculated for benthic prey items. The depth RSF was calculated by dividing the number of prey items collected within each $20 \mathrm{~m}$ bin by the amount $\left(\mathrm{km}^{2}\right)$ of ocean floor available within that depth range within $60 \mathrm{~km}$ to the west of the colony. All RSF values were then normalized so that all values for each prey item summed to 1 .

\section{RESULTS}

Birds with Lotek TDRs $\left(3.93 \pm 2.29\right.$ feeds $\left.\mathrm{d}^{-1}\right)$ did not have feeding rates significantly different from those of their mates without TDRs $\left(3.37 \pm 2.69\right.$ feeds d $^{-1}$; paired $t_{24}=0.58, \mathrm{p}=0.72$ ) or comparing the same bird with or without a TDR $\left(3.12 \pm 2.64\right.$ feeds $\mathrm{d}^{-1}$; paired $t_{24}=1.85$, $\mathrm{p}=0.96)$. Birds with Benvenuti TDRs $(2.07 \pm 1.10$ feeds $\mathrm{d}^{-1}$ ) had significantly fewer feeds than their mates (3.64 \pm 2.82 feeds $\mathrm{d}^{-1}$; paired $\left.t_{20}=2.35, \mathrm{p}=0.01\right)$. We could not compare observations on the same individuals with and without Benvenuti TDRs, as there were very few observations. There was no difference in time spent at the colony (but not brooding) between birds with Lotek TDRs $(5.53 \pm 11.00 \mathrm{~min})$ and their mates without TDRs $\left(6.10 \pm 19.22 \mathrm{~min}_{i} t_{1862}=0.82, \mathrm{p}=0.41\right)$, or between birds with Benvenuti TDRs (7.70 \pm $15.22 \mathrm{~min})$ and their mates without TDRs $(7.65 \pm$ $\left.13.15 \min _{;} t_{131}=0.07, \mathrm{p}=0.94\right)$.

A GLM (generalised linear model) with dive depth and prey species as independent variables showed a significant relationship among prey species and both water temperature $\left(F_{10,25263}=31.86, \mathrm{p}<0.0001\right.$, Fig. $\left.4 \mathrm{a}\right)$ and descent rate $\left(F_{10,7268}=27.13, \mathrm{p}<0.0001\right.$, Fig. $\left.4 \mathrm{~b}\right)$. Post-hoc $t$-tests showed that (1) murres returning with amphipods and sand lance descended during the final dives significantly slower than murres returning with any other prey item, (2) fish doctors were caught during dives with significantly higher temperature readings (across all depths) than other prey items, (3) squid were caught during dives with significantly lower temperature readings (across all depths) than other prey items, and (4) all other groupings were statistically homogeneous (Fig. 4).

Depth and duration of dives varied significantly amongst prey species, with squid obtained on long, deep dives and Arctic shanny, snakeblenny and fish doctor on short, shallow dives and the remaining prey items at a wide variety of depths and dive durations 
(Fig. 5, Table 2). Flight time generally increased with mass, as amphipods and squid were captured prior to short return flights, whereas fish doctor, snakeblenny, daubed shanny and Arctic cod were captured prior to long return flights (Fig. 5, Table 2). This could also be deduced from the observation that birds returning with amphipods often arrived at the colony still wet, whereas birds returning with fish doctors often arrived at the colony with fish that were so dry chicks had difficulty eating them. Pelagic prey items, such as amphipods and squid, were primarily captured after V-shaped dives, whereas benthic prey items, such as snakeblenny, fish doctor, Arctic shanny and daubed shanny, were usually caught after flat-bottomed dives; Arctic cod, capelin, sandlance and sculpin were caught in a wide variety of both dive types (Fig. 5, Table 2).

The MDAs reflected many of these similar trends, with capelin, sculpin, shrimp and Arctic cod poorly distinguished and the remaining species well-separated, especially once depth was included as a variable (Fig. 5). The MDA including all years generally distinguished amphipods and squid from benthic prey items, but benthic prey items tended to overlap with one another (Fig. 5a; $\chi^{2}=611.73$; df $=40$; Wilk's lambda $=0.4181$ ). Snakeblenny and Arctic shanny were particularly poorly resolved (Fig. 5a). Once depth was included, and only data from the Lotek TDRs (2004 to 2007) were used, the MDA distinguished amphipods, fish doctor, daubed shanny, Arctic shanny, snakeblenny, squid and sand lance with close to $95 \%$ accuracy (Fig. 5b; $\chi^{2}=577.79 ; \mathrm{df}=40 ;$ Wilk's lambda $=0.3845$ ). It must be kept in mind that some misidentification of prey items inevitably occurs and that some of the extreme datapoints may actually represent misidentifications.

Seventy two percent of the variation in dive behavior could be reduced to 3 axes (Table 3). The first component, PC1, accounted for $37 \%$ of the variance. Dive depth had the highest loading on $\mathrm{PC} 1$, and the remaining variables with high loadings on PC1 were closely linked to dive depth, such as dive duration, surface pause duration and minimum temperature during the dive. $\mathrm{PC} 2$ accounted for $24 \%$ of the variation. Return flight time had the highest loading on $\mathrm{PC} 2$, followed by the number of dives in the final dive bout. In a separate PCA, where all dives were included, number of dives in the final dive bout had the highest loading on PC2. Thus, it

Table 2. Uria lomvia. Prey, final dive depth, proportion of V-shaped dives during the final dive bout and return flight time preceding prey deliveries at Coats Island, Nunavut (see Fig. 1 for location) 2004 to 2007. Mean values (SD) are given. Statistical values for ANOVAs comparing differences among prey items are shown

\begin{tabular}{|c|c|c|c|c|}
\hline Prey delivered & $\mathrm{N}$ & $\begin{array}{l}\text { Depth of } \\
\text { final } \\
\text { dive }(\mathrm{m})\end{array}$ & $\begin{array}{l}\text { Proportion of } \\
\text { V-shaped dives in } \\
\text { final dive bout }\end{array}$ & $\begin{array}{l}\text { Mean return } \\
\text { flight time } \\
\text { (min) }\end{array}$ \\
\hline Arctic shanny & 12 & $29(17)$ & $0.11(0.29)$ & $24(11)$ \\
\hline Fish doctor & 10 & $32(26)$ & $0.02(0.06)$ & $24(10)$ \\
\hline Snakeblenny & 12 & $37(21)$ & $0.05(0.10)$ & $26(12)$ \\
\hline Shrimp & 4 & $43(26)$ & $0.19(0.39)$ & $19(9)$ \\
\hline Sandlance & 13 & $46(39)$ & $0.38(0.46)$ & $13(14)$ \\
\hline Capelin & 89 & $63(36)$ & $0.47(0.44)$ & $23(14)$ \\
\hline Amphipod & 11 & $68(18)$ & $1.00(0.00)$ & $6(4)$ \\
\hline Arctic cod & 36 & $69(37)$ & $0.28(0.39)$ & $25(12)$ \\
\hline Sculpin & 39 & $74(36)$ & $0.15(0.32)$ & $21(13)$ \\
\hline Gymnocanthus & 1 & 13 & 0.0 & 16 \\
\hline Triglops & 18 & 85 (29) & $0.05(0.15)$ & $24(15)$ \\
\hline Daubed shanny & 34 & $82(29)$ & $0.16(0.32)$ & $22(12)$ \\
\hline Squid & 11 & $93(23)$ & $0.72(0.35)$ & $13(8)$ \\
\hline Atlantic poacher & 1 & 115 & 0.2 & 14 \\
\hline$F_{9,258}$ & & $\begin{array}{c}6.26 \\
(\mathrm{p}<0.00001)\end{array}$ & $\begin{array}{c}10.51 \\
(\mathrm{p}<0.00001)\end{array}$ & $\begin{array}{c}3.67 \\
(p=0.0002)\end{array}$ \\
\hline
\end{tabular}

Table 3. Component loadings of 17 variables from the final dive or final dive bout of thick-billed murres preceding prey deliveries at Coats Island, Nunavut (see Fig. 1 for location) 2004 to 2007, which collectively explained $72 \%$ of total variance in the data. Parameters accounting for most of the variation in each principal component are shown in bold

\begin{tabular}{|lrrr|}
\hline Variable & PC1 & PC2 & PC3 \\
& $37 \%$ & $24 \%$ & $11 \%$ \\
\hline Depth of final dive & $\mathbf{- 0 . 4 0}$ & 0.05 & 0.05 \\
Average depth of dives during final bout & $\mathbf{- 0 . 4 0}$ & 0.06 & 0.04 \\
Duration of final dive & $\mathbf{- 0 . 3 8}$ & 0.06 & -0.06 \\
Average duration of dives during final bout & $\mathbf{- 0 . 3 6}$ & 0.01 & -0.17 \\
Average surface pause of dives during final bout & $\mathbf{- 0 . 3 4}$ & 0.09 & -0.04 \\
Average ratio of surface pause to dive duration & $\mathbf{- 0 . 3 0}$ & 0.06 & -0.05 \\
Temperature at maximum depth & $\mathbf{0 . 3 7}$ & 0.16 & -0.02 \\
Return flight time & 0.14 & $\mathbf{0 . 7 5}$ & 0.28 \\
Number of dives in the final bout & 0.21 & $\mathbf{0 . 4 7}$ & -0.20 \\
Proportion of V-shaped dives & -0.07 & 0.06 & $\mathbf{0 . 5 9}$ \\
TAD index & -0.04 & -0.02 & $\mathbf{0 . 4 0}$ \\
Sea surface temperature & 0.18 & -0.07 & $\mathbf{0 . 3 7}$ \\
SD surface pause of dives during final bout & -0.22 & 0.20 & $\mathbf{0 . 3 5}$ \\
Descent rate index & 0.04 & -0.11 & $\mathbf{0 . 3 5}$ \\
SD duration of dives during final bout & 0.00 & -0.10 & $\mathbf{0 . 2 2}$ \\
SD depth of dives during final bout & -0.02 & -0.06 & $\mathbf{0 . 2 1}$ \\
Temperature index & 0.05 & 0.19 & $\mathbf{- 0 . 2 3}$ \\
aTime-allocation-at-depth (TAD) index after Takahashi et al. $(2003)$ & \\
\hline
\end{tabular}


appeared that eliminated bouts with $<3$ dives may have removed some of the loading of number of dives on PC2. PC3 accounted for $11 \%$ of the variation. Dive shape had the highest loading on PC3, and the remaining variables with high loadings on PC3 were closely linked to either dive shape, such as the TAD index, or to prey lifestyle (benthic/pelagic), such as descent rate and water temperature.

All 11 birds fitted with radiotransmitters fed to the west of the colony. In 1998, the average number of incoming birds ( $\mathrm{n}=3$ watches) was 3828 birds $\mathrm{h}^{-1}$ from the west, 821 birds $\mathrm{h}^{-1}$ from the north and 366 birds $\mathrm{h}^{-1}$ from the east. In 2006, there were more incoming birds with fish from the west than the east during all 10 observations (ratio of west to east: range, 8-420; mean $=28 ; \mathrm{SD}=12 ; \mathrm{n}=10$ ). In 2007, the average number of incoming birds ( $\mathrm{n}=3$ watches) was 9600 birds $\mathrm{h}^{-1}$ from the west, 540 birds $\mathrm{h}^{-1}$ from the north and 240 birds $\mathrm{h}^{-1}$ from the east. It was apparent that most feeding occurred to the west of the colony.

Mapping locations of presumed prey capture showed definite groupings between prey types (Fig. 1). Sculpin captures were clustered along the narrow shelf east of Bencas Island, including areas quite close to the colony. Fish doctor captures were clustered on the shallow bench west of Bencas Island. Snakeblenny and Arctic shanny were taken on the bench in the vicinity of Bencas Island. There were few captures of any prey item in the very shallow region shoreward of Bencas Island.

After accounting for the proportion of depths available within $60 \mathrm{~km}$ of the colony, a univariate analysis

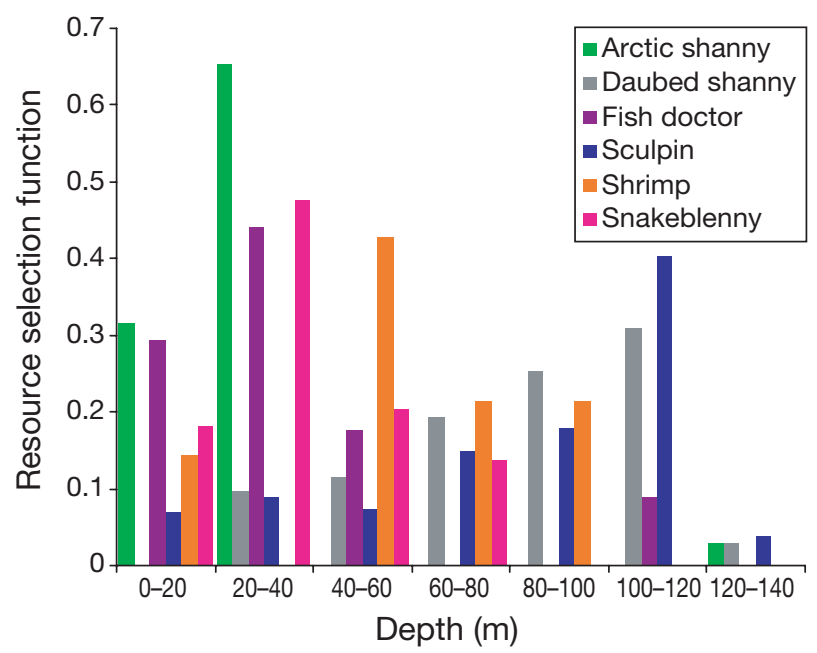

Fig. 6. Proportion of benthic prey items taken by thick-billed murres at each depth (resource selection function, RSF) as a function of the amount of available seafloor at that depth within $60 \mathrm{~km}$ of the Coats Island, Nunavut colony (see Fig. 1 for location) 2004 to 2007 . The RSF was calculated by dividing the number of prey items collected within each $20 \mathrm{~m}$ depth bin by the amount $\left(\mathrm{km}^{2}\right)$ of ocean floor available within that depth range. This value was then normalized so that for each prey item values summed to 1

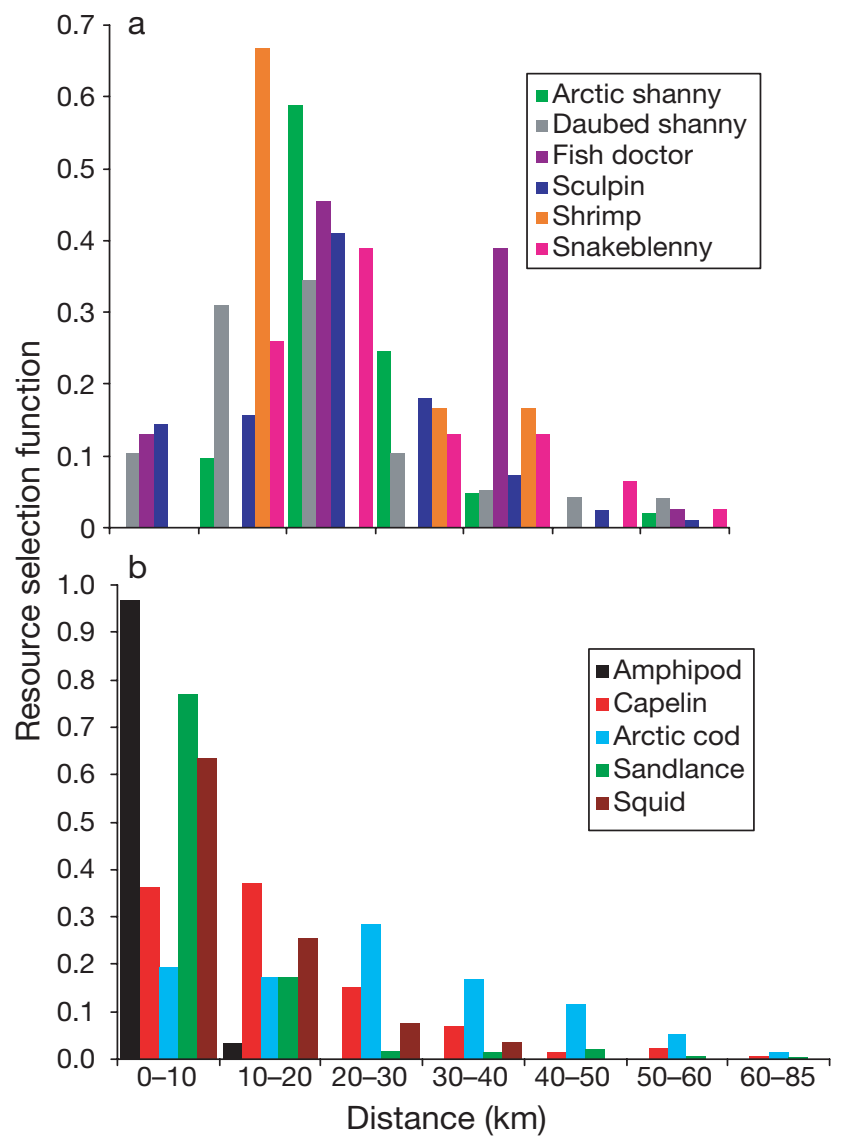

Fig. 7. Proportion of (a) benthic and (b) pelagic prey items taken by thick-billed murres at each $10 \mathrm{~km}$ distance interval as a function of the amount of ocean area available (resource selection function, RSF) around the Coats Island, Nunavut, colony (see Fig. 1 for location) 1999 to 2007. The RSF was calculated by dividing the number of prey items collected within each $10 \mathrm{~km}$ bin by the amount $\left(\mathrm{km}^{2}\right)$ of ocean surface available within that distance range. The RSF values were then normalized so that for each prey item values summed to 1

of dive depths for benthic species relative to available depths showed that depths were selected nonrandomly, with fish doctor and snakeblenny captured at shallower depths than other species $\left(F_{6,35}=3.37 ; \mathrm{p}=\right.$ 0.01; Fig. 6). A similar analysis of flight distance relative to ocean surface available showed that flight distances were chosen non-randomly for both benthic $\left(F_{6,35}=5.51 ; \mathrm{p}=0.0004\right)$ and pelagic $\left(F_{6,28}=11.25_{i} \mathrm{p}<\right.$ $0.0001)$ prey items, with amphipods, daubed shanny and capelin taken closer to the colony and snakeblenny taken farther from the colony (Fig. 7).

\section{DISCUSSION}

Thick-billed murre search-and-capture strategies varied significantly among 'specialist' prey items, such as fish doctor and amphipods (Table 2, Fig. 5). More 
'generalist' prey items, such as capelin, Arctic cod and sculpin, were captured using a variety of different foraging strategies (Fig. 5). For example, at the 95\% level there was almost no overlap between 6 different prey items (squid, snakeblenny, amphipods, Arctic shanny, fish doctor, daubed shanny and amphipods) (Fig. 5b). These results suggest that murres tailored their dive behaviour to increase capture rates of specific prey items, as has been shown to occur with other marine predators (cf. Kvitek et al. 1993, Garthe et al. 2000, Estes et al. 2003, Svanbäck \& Eklöv 2003).

Coats Island is known to have many adult 'specialist' murres that provision their chicks year after year with the same rare prey items. This observation, coupled with our results, suggests that adults specialize by using foraging strategies, including dive behaviour and locations, that are tailored for capture of a given prey type; dive profiles were usually remarkably constant for a given individual across years. For example, adults provisioning with amphipods usually returned visibly wet from a single trip lasting less than 30 min with a single, deep dive. Adults provisioning with fish doctors repeatedly returned with a very dry fish and the TDR traces invariably showed a long series of shallow Ushaped dives, to identical depths, followed by a lengthy return flight time. These birds apparently did not sample their environment but instead use past experience to forage at a location where amphipods or fish doctors were known to be accessible (Davoren et al. 2003).

\section{Dive depth, foraging effort and dive shape}

Dive behaviour varied along approximately 3 different major axes (Table 3) representing (1) dive depth, (2) flight time and number of dives in a bout, and (3) dive shape and standard deviation of dive behaviour. Tremblay \& Cherel (2003) also found that the foraging behaviour of rockhopper penguins (Eudyptes chrysocome) could be reduced to 3 axes, which they labeled dive mode (e.g. depth, duration), diving pattern (e.g. trip duration, number of dives) and variation of behaviour (e.g. standard deviation of dive depth). Thus, their results were remarkably similar to our own.

The depth axis likely reflects the depth range at which the prey items were accessible to murres. As depth, dive duration and surface pause duration are all closely correlated (Croll et al. 1992), it is unsurprising that these variables all contain similar information. As water temperature decreased with depth, it is also unsurprising that minimum temperature was closely correlated with depth. The depth range utilized did not merely represent the availability (e.g. local bathymetry; Figs. 1 \& 6). Rather, some prey items were clearly associated with shallow (e.g. Arctic shanny, fish doctor) or deep (Trig- lops, daubed shanny) water. The non-random use of different depths is consistent with the observation that marine mammals also select certain depths for foraging (e.g. Sjoberg \& Ball 2000, Laidre et al. 2004).

Small prey items (e.g. amphipods, squid, sandlance) were generally caught close to the colony on bouts with few dives, whereas large prey items (e.g. fish doctor, Arctic cod) were generally caught far from the colony on bouts with many dives (Fig. 5, Table 2). As flight time and number of dives correlated with prey mass, PC2 axis appeared to represent foraging effort. Thus, parental murres were apparently able to adjust their foraging effort by altering flight time and dive bout length.

Dive shape variation likely represents benthic versus pelagic foraging, with pelagic prey items (squid, amphipods) caught primarily on V-shaped dives and benthic prey items (shannies, sculpins, shrimp) caught primarily on U-shaped dives. The V-pelagic and U-benthic dichotomy had been deduced previously because pelagic foragers generally have V-shaped dives (Benvenuti et al. 2001, Schreer et al. 2001, Kato et al. 2003, Kuroki et al. 2003), whereas benthic foragers generally have U-shaped dives (Rodary et al. 2000, Schreer et al. 2001, Gazo et al. 2006). Nonetheless, species with strongly stratified epipelagic prey also show U-shaped dive patterns (Chappell et al. 1993), and some species show both dive patterns when foraging. For example, gannets display U-shaped dives when feeding on capelin schools and V-shaped dives when feeding on surface fish (Garthe et al. 2000). During our study, U-shaped dives sometimes preceded deliveries of squid and capelin, and it is likely that these dives also represented pursuit of schools at a specific depth. Thus, although our results support the generalization that $\mathrm{V}$-shaped dives are pelagic and U-shaped dives are benthic, the agreement was not perfect. Other researchers have used other classifications of dive shape, including left or right-skewed dives, or the number of wiggles or steps per dive (Schreer et al. 2001, Simeone $\&$ Wilson 2003). Additional analysis of dive shape, coupled with bird-borne cameras (Takahashi et al. 2004) or stomach temperature loggers (Simeone \& Wilson 2003), may provide greater information on foraging strategies.

The dive shape axis (PC3) also had the highest loading for descent rate, water temperature, sea surface temperature and standard deviation of depth, duration and surface pause duration. Descent rate tended to decrease for pelagic prey items, such as amphipods and sandlance (Fig. 4, Table 3). Presumably, pelagic foragers reduce descent rate to search through the water column, whereas benthic foragers increase descent rate to minimize travel time and maximize bottom time. Water temperature was low during dives resulting in capture of squid (pelagic) and higher during dives resulting in the capture of fish doctor 
(benthic), resulting in a correlation between water temperature and prey lifestyle. The seafloor provides a distinct destination, and it is presumably for this reason that benthic items tended to have lower standard deviations than pelagic prey items (Table 3). Thus, there were numerous correlates for prey lifestyle, the strongest of which appeared to be dive shape.

\section{Foraging behaviour for each prey type}

Invertebrates

Invertebrates tended to be captured close to the colony, with squids and amphipods usually caught on $\mathrm{V}$-shaped dives and shrimp on U-shaped dives.

Amphipods. Birds returning with amphipods revealed the most clearcut behavioural pattern. They were caught on moderately deep, V-shaped dives with very short return flight time (Tables 1 \& 2, Fig. 7). Descent rate was slow (Fig. 4), suggesting that murres may have been searching for prey items while descending. Endo et al. (2000) found that Adélie penguins (Pygoscelis adeliae) specializing on fish dove shallower than those specializing on krill, although RopertCoudert et al. (2002) found no difference in the dive behaviours of fish-specializing and krill-specializing Adélie penguins.

Shrimp. Shrimp foraging behaviour was not readily discriminated (Fig. 5). This may be because (1) murres did not have specific strategies for this prey item, (2) sample size was small, or (3) several different species of shrimp, each associated with different foraging behaviours, were pooled together. As a general pattern, shrimp tended to be captured during U-shaped dives and therefore clumped with the benthic prey items.

Squid. Squids were caught during deep, primarily V-shaped dives with short return flight time (Table 2, Fig. 5). These observations are consistent with the deep, pelagic distribution of Gonatus in the Arctic (Table 1). Water temperature was particularly low (Fig. 4), suggesting that they may have been associated with upwellings, where cold lower layers were brought to the surface. Thus, squid may be associated with the deep trough immediately north of the colony, where upwellings are known to occur. Although squid is a relatively rare item at Coats Island (Gaston et al. 2003), it is an important prey item in the Pacific.

\section{Pelagic fish}

Pelagic fish were caught using many different foraging strategies, and the foraging behaviours for 2 of the
3 species were poorly discriminated. In general, pelagic fish tended to be caught during V-shaped dives, with sandlance also frequently caught on U-shaped dives and Arctic cod on U-shaped dives.

Capelin. Capelin were caught during a wide variety of different dive behaviours (Fig. 5), possibly because they occupied a wider variety of habitats than most prey items (Table 1). Alternatively, capelin may have been caught as a secondary option when a foraging bout tailored towards a more profitable item was unsuccessful. For example, in several cases, individual specialists that normally returned with specialist prey items (e.g. fish doctor, daubed shanny) would return with capelin. The preceding dive bout appeared visually identical to the dive bout preceding delivery of the specialist prey items, suggesting that perhaps the individual was searching for the specialist prey item, but when it was not encountered, the bird returned with capelin.

Sandlance. Sandlance were captured at shallow depths (Table 2). In 2004 to 2007 they were captured close to the colony, whereas in 1999 and 2000 they were captured quite far from the colony, perhaps representing a change in their local distribution. They were the only prey item regularly caught after $\mathrm{u}$-shaped dives, and they were often captured early or late in the day. The shallow, curved u-shaped dives may reflect capture from surface schools, as sand lance are frequently herded toward the surface by predators once they exit bottom sediments, generally at night.

Arctic cod. Arctic cod were a generalist prey item, captured at a wide variety of depths and distances from the colony. Nonetheless, they generally clumped with the benthic prey items (Fig. 5). This is surprising, as adult Arctic cod are usually found in large, pelagic schools during the ice-free period (Table 1), and larval Arctic cod grow more slowly when they are not near the surface. Nonetheless, little is known about the habitat preferences of 1 yr-old Arctic cod, especially at the southern limit of their range, and recent hydroacoustic surveys near the colony suggest that Arctic cod may inhabit the benthos during the ice-free period. Alternatively, the U-shaped dives may reflect capture in large schools at a defined depth (Mori et al. 2002). Rather surprisingly, Arctic cod were not captured more often in colder water than were other prey items, despite the cod usually being considered as preferring cold water.

\section{Benthic fish}

Benthic fish tended to be captured after U-shaped dives at a variety of depths and distances from the colony. 
Fish doctor. Fish doctors were taken with very distinctive dive bout profiles, characterized by a large number of very shallow dives, separated by virtually no surface pause and followed by a long return time (Table 2, Fig. 5). Fish doctor are known to associate with kelp forests (Table 1), and presumably, this prey item was collected from the kelp forests around Bencas Island. The relatively warm temperature profiles suggest that the fish are taken from areas protected from cold ocean currents, such as the extensive kelp forests on the bench near Bencas Island.

Daubed shanny. Daubed shannies were caught on 2 different dive bout patterns. The first pattern involved short flight times and deep dives with very little bottom time (Fig. 5). The second pattern involved longer flight times, and shallower dives with longer bottom time (Figs. 5 to 7). This may reflect the scarcity of daubed shanny at shallow depths near the colony, possibly due to depletion by murres. Daubed shanny capture depths and distances were trimodal (Fig. 1), suggesting that suitable substratum for this species may be patchy. The recorded dive depths for daubed shanny were quite shallow for this species, which normally occurs in deep water (Table 1); murres regularly dive very deep off the Gannet Islands, Newfoundland, Canada, where daubed shanny is the dominant prey item (Bryant et al. 1999, Jones et al. 2002).

Arctic shanny. Arctic shannies were captured after relatively shallow, U-shaped dive bouts in the vicinity of Bencas Island (Table 2, Fig. 1), suggesting that they may have occurred on the rocky substratum or with kelp around the island.

Snakeblenny. Snakeblennies were captured after shallow to moderately deep, distant dive bouts (Table 2, Figs. 6 \& 7). All prey captures were estimated to be from the bench near Bencas Island (Fig. 1), where presumably suitable rocky substratum occurs. In general, dive behaviour and foraging locations were similar to those for Arctic shannies and fish doctors, but tended to be deeper (Fig. 6).

Sculpin. Sculpins were caught after a wide variety of dive behaviours (Fig. 5). It is unclear whether this is because they were a generalist prey item, possibly caught as a secondary option when a foraging bout did not encounter a higher quality prey item, or whether this reflects inclusion of several different species in the single Sculpin category. In many cases, sculpins were caught along the narrow shelf along the colony (Fig. 1), suggesting that the fish may have been caught on the return trip when no higher quality prey item was captured. As expected, the shallow water Gymnocanthus was caught in shallower water than the deep water Triglops (Tables 1 \& 2). Our single observation of Atlantic poacher was made following a very deep dive (Table 2). Patterns for sculpin capture may be compli- cated by spawning behaviour, as sculpins were among the few taxa that likely spawned during the observation period (Table 1), and we have collected gravid sculpins. Sculpins were caught on V-shaped dives more often than other benthic fish, suggesting that sculpins, especially Triglops, may occasionally forage in the water column, as has been suggested from stomach content data (Atkinson \& Percy 1998). Sculpins may be easier to capture when foraging in the water column, as they would not be hidden and/or camouflaged beneath rocks or sand.

\section{Implications for seabirds as indicators}

Results show that these generalist predators (murres) are not merely naïve, random predators and, hence, the proportion of a given prey item in diets does not reflect only encounter rates. Clearly, the underlying principles of at-sea decision-making and searching by murres must be better understood before diet and time budgets can be translated into at-sea prey abundance. Nonetheless, results suggest that these generalist predators may be useful indicators of the horizontal and vertical distribution of their prey, as well as total prey abundance (Monaghan et al. 1994). Furthermore, although some individuals specialized on certain prey items across years, other individuals switched prey items between years and within a year. These differences presumably reflect behavioural decisions made by adult murres in response to perceived changes in prey abundance. Thus, TDRs allow researchers to monitor not only temporal trends in seabird behavior, but also how they change for specific prey types, which presumably reflects changes in the biology and behaviour of the prey.

Acknowledgements. We thank K. Ashbrook, M. Barrueto, A. Hargreaves, S. Jacobs, G. Lancton, T. Lash, A. Moody, J. Provencher, A. Ronston, P. Smith, U. Steiner, L. Wilson and P. Woodward for help in the field. A. Fromevitch, K. Hedges and P. Turko helped with data compilation. J. Nakoolak kept us safe from bears. S. Jacobs commented on an earlier version of the manuscript. J. Higdon, S. Kennedy, A. Robinson and A. Smith aided with GIS and provided GEBCO data. K.H.E benefited from funding provided by a NSERC Postgraduate (M) Award, NSERC Northern Research Internship, Dr. Andrew Taylor Research Grant, Malcolm Ramsay Memorial Grant, Mountain Equipment Co-op Studentship, Arctic Institute of North America Grant-in-aid, Frank M. Chapman Memorial Fund and Society of Canadian Ornithologists/Bird Studies Canada Taverner Award. K.H.E and K.W. benefited from the Northern Scientific Training Program of the Department of Indian Affairs and Northern Development. The University of Pisa and Ministero della Ricerca Scientifica e Tecnologica provided funding for S.B. and L.D. The Canadian Wildlife Service Migratory Birds Division, the Polar Continental Shelf Project and the University of Manitoba also funded 
this project. R. Armstrong at the Nunavut Research Institute, M. Mallory at the Canadian Wildlife Service Northern Research Division and C. Eberl at the National Wildlife Research Centre provided logistical support. This project was completed as part of the M Sc requirements at the University of Manitoba for K.H.E and the University of Ottawa for K.W. Finally, we would like to thank the birds on the ' $\mathrm{Q}$ ' ledges for their cooperation - this project would not have been possible without them.

\section{LITERATURE CITED}

Aebischer NJ, Coulson JC, Colebrook JM (1990) Parallel long-term trends across four marine trophic levels and weather. Nature 347:753-755

Atkinson EG, Percy JA (1992) Diet comparison among demersal marine fish from the Canadian Arctic. Polar Biol 11: 567-573

Barrett RT (2002) Atlantic puffin Fratercula arctica and common guillemot Uria aalge chick diet and growth as indicators of fish stocks in the Barents Sea. Mar Ecol Prog Ser 230:275-287

Barrett RT, Rov N, Loen J, Montevecchi WA (1990) Diets of shags Phalacrocorax aristotelis and cormorants $P$. carbo in Norway and possible implications for gadoid stock recruitment. Mar Ecol Prog Ser 66:205-218

Benvenuti S, Bonadonna F, Dall'Antonia L, Gudmundsson GA (1998) Foraging flights of breeding thick-billed murres (Uria lomvia) as revealed by bird-borne direction recorders. Auk 115:57-66

Benvenuti S, Dall'Antonia L, Lyngs P (2001) Foraging behaviour and time allocation of chick-rearing Razorbills Alca torda at Graesholmen, central Baltic Sea. Ibis 143: 402-412

Bertram DF, Kaiser GW (1993) Rhinoceros auklet (Cerorhinca monocerata) nestling diet may gauge Pacific sand lance (Ammodytes hexapterus) recruitment. Can J Fish Aquat Sci 50:1908-1915

Boyd IL, Croxall JP (1992) Diving behaviour of female Antarctic fur seals. Can J Zool 70:919-928

Bryant R, Jones IL, Hipfner JM (1999) Responses of common and thick-billed murres to changes in prey availability at the Gannet Islands, Labrador. Can J Zool 77:1278-1287

Burns JM, Schreer JF, Castellini MA (1997) Physiological effects on individual dive patterns and foraging strategies in yearling Weddell seals. Can J Zool 75:1796-1810

Catry P, Phillips RA, Phalan B, Silk JRD, Croxall JP (2004) Foraging strategies of grey-headed albatrosses Thalassarche chrysostoma: integration of movements, activity and feeding events. Mar Ecol Prog Ser 280:261-273

Chappell MA, Shoemaker VH, Janes DN, Bucher TH, Maloney SK (1993) Diving behavior during foraging in breeding Adélie penguins. Ecology 74:2450-2461

Charrassin JB, Kato A, Handrich Y, Sato K and others (2001) Feeding behaviour of free-ranging penguins determined by oesophageal temperature. Proc Roy Soc Lond B 268: 151-157

Croll DA, Gaston AJ, Burger AE, Konnoff D (1992) Foraging behaviour and physiological adaptation for diving in thick-billed murres. Ecology 73:344-356

Davoren GK, Montevecchi WA (2003) Signals from seabirds indicate changing biology of capelin stocks. Mar Ecol Prog Ser 258:253-261

Davoren GK, Montevecchi WA, Anderson JT (2003) Search strategies of a pursuit-diving marine bird and the persistence of prey patches. Ecol Monogr 73:463-481
Elliott KH, Gaston AJ (2005) Flight speeds of two seabirds: a test of Norberg's hypothesis. Ibis 147:783-789

Elliott KH, Davoren GK, Gaston AJ (2007) The influence of buoyancy and drag on the dive behaviour of an Arctic seabird, the thick-billed murre. Can J Zool 85:352-361

Endo Y, Asari H, Watanuki Y (2000) Biological characteristics of euphausiids preyed upon by Adélie penguins, Pygoscelis adeliae, breeding at Hukuro Cove, LützowHolm Bay in 1995/1996. Polar Biosci 13:66-73

Estes JA, Riedman ML, Staedler MM, Tinker MT, Lyon BE (2003) Individual variation in prey selection by sea otters: patterns, causes and implications. J Anim Ecol 72:144-155

Falk K, Benvenuti S, Dall'Antonia L, Kampp K, Rioblini A (2000) Time allocation and foraging behaviour of chickrearing Brunnich's guillemots Uria lomvia in high-arctic Greenland. Ibis 142:82-92

Falk K, Benvenuti S, Dall'Antonia L, Gilchrist G, Kampp K (2002) Foraging behaviour of thick-billed murres breeding in different sectors of the North Water polynya: an intercolony comparison. Mar Ecol Prog Ser 231:293-302

Furness RW, Camphuysen CJ (1997) Seabirds as monitors of the marine environment. ICES J Mar Sci 54:726-737

Garthe S, Benvenuti S, Montevecchi WA (2000) Pursuit plunging by Northern Gannets (Sula bassana) feeding on capelin (Mallotus villosus). Proc R Soc Lond Biol Sci 267: $1717-1722$

Gaston AJ (2004) Seabirds: a natural history. Oxford University Press, Oxford

Gaston AJ, Woo K, Hipfner JM (2003) Trends in forage fish populations in northern Hudson Bay since 1981, as determined from the diet of nestling thick-billed murres Uria lomvia. Arctic 56:227-233

Gaston AJ, Gilchrist HG, Hipfner JM (2005) Climate change, ice conditions and reproduction in an Arctic nesting marine bird: Brünnich's guillemot (Uria lomvia L.). J Anim Ecol 74:832-841

Gazo M, Lydersen C, Aguilar A (2006) Diving behaviour of Mediterranean monk seal pups during lactation and post weaning. Mar Ecol Prog Ser 308:303-309

Grémillet D (1997) Catch per unit effort, foraging efficiency, and parental investment in breeding great cormorants (Phalacrocorax carbo carbo). ICES J Mar Sci 54:635-644

Harding AMA, Piatt JF, Schmutz JA, Shultz MT, Van Pelt TI, Kettle AB, Speckman SG (2007) Prey density and the behavioral flexibility of a marine predator: the common murre (Uria aalge). Ecology 88:2024-2033

Hipfner JM, Gaston AJ, Smith BD (2006) Regulation of provisioning in the thick-billed murre (Uria lomvia). Can J Zool 84:931-938

Jones IL, Fraser GS, Rowe S, Carr X, Taylor P (2002) Different patterns of parental effort during chick-rearing by female and male thick-billed murres (Uria lomvia) at a low Arctic colony. Auk 119:1064-1074

Jodice PGR, Roby DD, Suryan RM, Irons DB and others (2006) Increased energy expenditure by a seabird in response to higher food abundance. Mar Ecol Prog Ser 306:283-293

Kato A, Watanuki Y, Naito Y (2003) Foraging behaviour of chick-rearing rhinoceros auklets Cerorhinca monocerata at Teuri Island, Japan, determined by acceleration-depth recording micro data loggers. J Avian Biol 34:282-287

Kirkwood R, Robertson G (1997) The foraging ecology of female emperor penguins in winter. Ecol Monogr 67: 155-176

Kvitek RG, Bowlby CE, Staedler M (1993) Diet and foraging behavior of sea otters in southeast Alaska. Mar Mamm Sci 9:168-181

Kuroki M, Kato A, Watanuki Y, Niizuma Y, Takahashi A, 
Naito Y (2003) Diving behavior of an epipelagically feeding alcid, the Rhinoceros Auklet (Cerorhinca monocerata) Can J Zool 81:1249-1256

Laidre KL, Heide-Jørgensen MP, Logdson ML, Hobbs RC and others (2004) Seasonal narwhal habitat associations in the high Arctic. Mar Biol 145:821-831

Lescroël A, Bost CA (2005) Foraging under contrasting oceanographic conditions: the gentoo penguin at Kerguelen Archipelago. Mar Ecol Prog Ser 302:245-261

Lovvorn JR, Croll DA, Liggins GA (1999) Mechanical versus physiological determinants of swimming speeds in diving Brünnich's guillemots. J Exp Biol 202:1741-1752

Lovvorn JR, Watanuki Y, Kato A, Naito Y, Liggins GA (2004) Stroke patterns and regulation of swim speed and energy cost in free-ranging Brünnich's guillemots. J Exp Biol 207: 4679-4695

MacArthur RH, Pianka ER (1966) On the optimal use of a patchy environment. Am Nat 100:603-609

Mehlum F, Watanuki Y, Takahashi A (2001) Diving behaviour and foraging habitats of Brünnich's guillemots (Uria lomvia) breeding in the High-Arctic. J Zool Lond 255: 413-423

Miller AK, Sydeman WJ (2004) Rockfish response to lowfrequency ocean climate change as revealed by the diet of a marine bird over multiple time scales. Mar Ecol Prog Ser 281:207-216

Monaghan P (1996) Relevance of the behaviour of seabirds to the conservation of marine environments. Oikos 77 : 227-237

Monaghan P, Walton P, Wanless S, Uttley JD, Burns MD (1994) Effects of prey abundance on the foraging behavior, diving efficiency and time allocation of breeding guillemots Uria aalge. Ibis 136:214-222

Montevecchi WA, Myers RA (1995) Prey harvests of seabirds reflect pelagic fish and squid abundance on multiple spatial and temporal scales. Mar Ecol Prog Ser 117:1-9

Montevecchi WA, Myers RA (1996) Dietary changes of seabirds indicate shifts in pelagic food webs. Sarsia 80 : 313-322

Mori Y, Yoda K, Sato K (2001) Defining dive bouts using a sequential differences analysis. Behaviour 138:1451-1466

Mori Y, Takahashi A, Mehlum F, Watanuki Y (2002) An application of optimal diving models to diving behaviour of Brünnich's guillemots. Anim Behav 64:739-745

Orians GH, Pearson NE (1979) On the theory of central place foraging. In: Horn DJ, Stairs GR, Michell RD (eds) Analysis of ecological systems. Ohio State University Press, Columbus, OH, p 155-177

Paredes R, Jones IL, Boness DJ (2004) Reduced parental care, compensatory behaviour and reproductive costs experienced by female and male thick-billed murres equipped with data loggers. Anim Behav 69:197-208

Pütz K, Cherel Y (2005) The diving behaviour of brooding king penguins (Aptenodytes patagonicus) from the Falkland Islands: variation in dive profiles and synchronous underwater swimming provide new insights into their foraging strategies. Mar Biol 147:281-290

Radl A, Culik BM (1999) Foraging behaviour and reproductive success in Magellanic penguins (Spheniscus magellanicus): a comparative study of two colonies in southern Chile. Mar Biol 133:381-393

Editorial responsibility: Rory Wilson,

Swansea, UK
Rodary D, Bonneau W, Le Maho Y, Bost CA (2000) Benthic diving in male emperor penguins Aptenodytes forsteri foraging in winter Mar Ecol Prog Ser 207:171-181

Ropert-Coudert Y, Kato A, Bost CA, Rodary D, Sato K, Le Maho Y, Naito Y (2002) Do Adélie penguins modify their foraging behaviour in pursuit of different prey? Mar Biol 140:647-652

Schreer JF, Kovacs KM, Hines RJO (2001) Comparative diving patterns of pinnipeds and seabirds. Ecol Monog 71: $137-162$

Simeone A, Wilson RP (2003) In-depth studies of Magellanic penguins (Spheniscus magellanicus) foraging: Can we estimate prey consumption by perturbations in the dive profile? Mar Biol 143:825-831

Sjoberg M, Ball JP (2000) Grey seal, Halichoerus grypus, habitat selection around haulout sites in the Baltic Sea: bathymetry or central-place foraging? Can J Zool 78: 1661-1667

Svanbäck R, Eklöv P (2003) Morphology-dependent foraging efficiency in perch: morphology: a tradeoff for ecological specialization? Oikos 102:273-284

Takahashi A, Dunn MJ, Trathan PN, Sato K, Naito Y, Croxall JP (2003) Foraging strategies of chinstrap penguins at Signy Island, Antarctica: importance of benthic feeding on Antarctic krill. Mar Ecol Prog Ser 250:279-289

Takahashi A, Sato K, Naito Y, Dunn MJ, Trathan PN, Croxall JP (2004) Penguin-mounted cameras glimpse underwater group behaviour. Proc Roy Soc Lond B 271:S281-S282

Tremblay Y, Cherel Y (2000) Benthic and pelagic dives: a new foraging behaviour in rockhopper penguins. Mar Ecol Prog Ser 204:257-267

Tremblay Y, Cherel Y (2003) Geographic variation in the foraging behaviour, diet and chick growth of rockhopper penguins. Mar Ecol Prog Ser 251:279-297

Tremblay Y, Cook TR, Cherel Y (2005) Time budget and diving behaviour of chick-rearing Crozet shags. Can J Zool 83:971-982

Ward P, Zahavi A (1973) The importance of certain assemblages as 'information centres' for food-finding. Ibis 115: 517-534

Watanuki Y, Mehlum F, Takahashi A (2001) Water temperature sampling by foraging Brünnich's Guillemots with bird-borne data loggers. J Avian Biol 32:189-193

Watanuki Y, Niizuma Y, Gabrielsen GW, Sato K, Naito Y (2003) Stroke and glide of wing-propelled divers: deep diving seabirds adjust surge frequency to buoyancy change with depth. Proc R Soc Lond B Biol Sci 270: 483-488

Watanuki Y, Wanless S, Harris M, Lovvorn JR, Miyazaki M, Tanaka H, Sato K (2006) Swim speeds and stroke patterns in wing-propelled divers: a comparison among alcids and a penguin. J Exp Biol 209:1217-1230

Weimerskirch H, Gault A, Cherel Y (2005) Prey distribution and patchiness: factors in foraging success and efficiency of wandering albatrosses. Ecology 86:2611-2622

Wilson RP, Culik BM, Peters G, Bannasch R (1996) Diving behaviour of Gentoo penguins, Pygoscelis papua: factors keeping dive profiles in shape. Mar Biol 126:153-162

Wilson RP, Scolaro JA, Grémillet D, Kierspel MAM and others (2005) How do Magellanic Penguins cope with variability in their access to prey? Ecol Mongr 75:379-401

Submitted: September 4, 2006; Accepted: August 8, 2007 Proofs received from author(s): January 25, 2008 